\title{
Novel biological activity of ameloblastin in enamel matrix derivative
}

\author{
Sachiko KURAMITSU-FUJIMOTO ${ }^{1}$, Wataru ARIYOSHI ${ }^{2}$, Noriko SAITO ${ }^{3}$, Toshinori OKINAGA ${ }^{2}$, Masaharu KAMO ${ }^{4}$, Akira \\ ISHISAKI $^{4}$, Takashi TAKATA ${ }^{5}$, Kazunori YAMAGUCHI ${ }^{1}$, Tatsuji NISHIHARA ${ }^{2}$
}

\footnotetext{
1- Division of Orofacial Functions and Orthodontics, Department of Growth Development of Functions, Kyushu Dental University, Fukuoka, Japan.

2- Division of Infections and Molecular Biology, Department of Health Promotion, Kyushu Dental University, Fukuoka, Japan.

3- Division of Pulp Biology, Operative Dentistry and Endodontics, Department of Cariology and Periodontology, Kyushu Dental University, Fukuoka, Japan.

4- Division of Cellular Biosignal Sciences, Department of Biochemistry, Iwate Medical University, Iwate, Japan.

5- Department of Oral and Maxillofacial Pathobiology, Institute of Biomedical and Health Sciences, Hiroshima University, Hiroshima, Japan.
}

Corresponding address: Tatsuji Nishihara - Division of Infections and Molecular Biology, Department of Health Promotion, Kyushu Dental University - 2-6-1 Manazuru - Kokurakita-ku - Kitakyushu - Fukuoka - 803-8580 - Japan - Phone: +81 932853050 - fax: +8193 5814984 - e-mail: tatsujin@kyu-dent.ac.jp

Submitted: July 24, 2014 - Modification: October 24, 2014 - Accepted: October 27, 2014

\section{ABSTRACT}

\begin{abstract}
bjective: Enamel matrix derivative (EMD) is used clinically to promote periodontal tissue regeneration. However, the effects of EMD on gingival epithelial cells during regeneration of periodontal tissues are unclear. In this in vitro study, we purified ameloblastin from EMD and investigated its biological effects on epithelial cells. Material and Methods: Bioactive fractions were purified from EMD by reversed-phase high-performance liquid chromatography using hydrophobic support with a C18 column. The mouse gingival epithelial cell line GE-1 and human oral squamous cell carcinoma line SCC-25 were treated with purified EMD fraction, and cell survival was assessed with a WST-1 assay. To identify the proteins in bioactive fractions of EMD, we used proteome analysis with two-dimensional gel electrophoresis followed by identification with liquid chromatography-tandem mass spectrometry (LC-MS/MS) analysis. Results: Purified fractions from EMD suppressed proliferation of GE-1 and SCC-25. LC-MS/MS revealed that ameloblastin in EMD is the component responsible for inhibiting epithelial cell proliferation. The inhibitory effect of ameloblastin on the proliferation of GE-1 and SCC-25 was confirmed using recombinant protein. Conclusion: The inhibitory effects of EMD on epithelial cell proliferation are caused by the biological activities of ameloblastin, which suggests that ameloblastin is involved in regulating epithelial downgrowth in periodontal tissues.
\end{abstract}

Keywords: Periodontitis. Periodontal guided tissue regeneration. Epithelial cells. Dental enamel proteins.

\section{INTRODUCTION}

Periodontitis is an inflammatory process caused by bacterial components and products that trigger the production of inflammatory molecules from cells in periodontal tissues. Cells in gingival connective tissue are targets for bacterial virulence factors and inflammatory mediators ${ }^{18}$. These factors stimulate gingival fibroblasts, macrophages, and lymphocytes to produce other inflammatory mediators, such as proinflammatory cytokines and prostanoids, which in turn induce matrix metalloproteinase production and activation, leading to extracellular matrix degradation ${ }^{9,22}$.

The primary aims of periodontal therapy are to control periodontal tissue inflammation and regain supporting tissue lost as a consequence of periodontal disease. Enamel matrix derivative (EMD) is beneficial in healing wounds and regeneration and is widely used to treat periodontal damage caused by periodontitis, as it promotes tissue regeneration and decreases inflammation after periodontal surgery ${ }^{12}$.

EMD is extracted from developing porcine embryonic enamel and contains hydrophobic enamel matrix proteins ${ }^{12}$ which are mainly composed of amelogenin and related proteins $s^{6,7,21}$. These proteins are important in the development of acellular cementum, the periodontal ligament, and alveolar bone. EMD has a variety of biological effects 
in vitro, such as regeneration of mesenchymal and epithelial cells, enhancement of wound healing via extracellular matrix synthesis, and the regulation of molecules involved in bone remodeling ${ }^{1,8}$. Genome-wide microarray approach demonstrated that EMD causes substantial alternations in gene expression, with similar patterns observed in palatal and gingival fibroblasts ${ }^{11}$.

It has been reported that EMD stimulated osteoclastogenesis via the NF-kappa $\mathrm{B}^{14}$ receptor activator ${ }^{20}$ or transforming growth factor-beta 1 signaling ${ }^{10}$. These results suggest that EMD provides a local environment suitable for bone regeneration in periodontal tissues because of its effects on bone remodeling activities such as bone formation and resorption. Furthermore, previous studies demonstrated that EMD inhibited the proliferation of primary human gingival keratinocytes ${ }^{29}$. However, the effects of EMD on gingival epithelial cells during regeneration of periodontal tissues are unclear. In this in vitro study, we purified ameloblastin from EMD and investigated its biological functions on epithelial cells.

\section{MATERIAL AND METHODS}

\section{Cell culture}

The mouse gingival epithelial cell line GE-1 was obtained from the Riken Cell Bank (Ibaraki, Japan). Cells were maintained in a serum-free medium (SFM-101; Nissui, Tokyo, Japan) supplemented with $1 \%$ fetal bovine serum (FBS; Gibco, Grand Island, $\mathrm{NY}$, USA), penicillin $\mathrm{G}(100 \mathrm{U} / \mathrm{mL})$, streptomycin $(100 \mu \mathrm{g} / \mathrm{mL})$, and epithelial growth factor (EGF; $1 \mu \mathrm{g} / \mathrm{mL}$ ). SCC-25 cells, which are derived from human squamous cell carcinoma of the tongue, were obtained from DS Pharmaceutical Co. (Osaka, Japan) and maintained in a 1:1 mixture of Dulbecco's modified Eagle's medium (DMEM) and Ham's F-12 medium supplemented with $10 \%$ FBS.

\section{Purification of EMD}

EMD (Biora, Malmö, Sweden) was kindly supplied by Seikagaku Corporation (Tokyo, Japan). Lyophilized material was dissolved in $0.1 \%$ trifluoroacetic acid (TFA) $(30 \mathrm{mg} / \mathrm{mL})$, after which reversed-phase high-performance liquid chromatography (HPLC) was performed using a Waters system (Midford, MA, USA) and $\mathrm{C}_{18}$ column $(4.6 \times 150 \mathrm{~mm}$; Vydac, Hesperia, CA, USA) equilibrated with $0.1 \%$ TFA. Fractions of $0.5 \mathrm{~mL}$ were collected at a flow rate of $0.5 \mathrm{~mL} /$ minute and assayed for epithelial cell proliferation, as described below. Protein content was determined using a BioRad protein assay reagent (Bio-Rad Laboratories, Richmond, CA, USA). Bioactive fractions that inhibited epithelial cell proliferation in the WST-1 assay were lyophilized, dissolved in the culture medium, and used in the cell culture assays.

\section{Expression and purification of recombinant ameloblastin}

The expression vector pcDNA3.1 was used to express FLAG-tagged human ameloblastin proteins, as previously described ${ }^{13}$. Expression plasmids were transfected into COS-7 cells by Nucleofection ${ }^{\text {TM }}$ using a 4D Nucleofector ${ }^{\mathrm{TM}}$ device (Lonza Japan Inc., Tokyo, Japan). After 2 days, transfected cells were lysed with lysis buffer ( $50 \mathrm{mM}$ Tris- $\mathrm{HCl}$ containing $150 \mathrm{mM} \mathrm{NaCl}, 1 \mathrm{mM}$ EDTA, and 1\% Triton $\mathrm{X}, \mathrm{pH}$ 7.4), and FLAG-tagged recombinant protein was partially purified with ANTI-FLAG ${ }^{\circledR}$ M2 Affinity Gel (Invitrogen, Grand Island, NY, USA), according to the manufacturer's instructions.

\section{WST- 1 analysis}

Cell viability was determined using tetrazolium salt WST-1 (4-[3-(4-iodophenyl)-2H-5-tetrazolium]1-3-benzene disulfonate; Wako Pure Chemical Industries, Ltd., Japan). GE-1 cells were plated in 96-well plates at a concentration of $1 \times 10^{4}$ cells/ well 3 hours before starting the experiment. Later, cells were stimulated with fractioned EMD or recombinant protein. After stimulated cells were cultured for 44 hours, WST-1 solution $(10 \mu \mathrm{L})$ was added to each well, followed by incubation for 4 hours. Absorbance at 450 and $630 \mathrm{~nm}$ was measured using a Multiskan JX Microplate Reader (Thermo Electron Co., Kanagawa, Japan).

\section{Silver stain}

HPLC-purified fractions were solubilized in lysis buffer $(75 \mathrm{mM}$ Tris- $\mathrm{HCl}$ containing 2\% SDS and $10 \%$ glycerol, $\mathrm{pH} 6.8$ ), then boiled for 5 minutes before electrophoresis. Sodium dodecyl sulfatepolyacrylamide gel electrophoresis (SDS-PAGE) was performed on $12.5 \%$ gels that were stained with 2D-Silver Stain (Daiichi Pure Chemicals Co., Tokyo, Japan), according to the manufacturer's instructions.

\section{Protein identification}

SDS-PAGE was done on $5-20 \%$ acrylamide gradient gels and visualized with silver stain. Single protein bands were cut after electrophoresis, after which the gel portion containing the protein was de-stained and washed with a 100-mM ammonium bicarbonate/acetonitrile $1: 1(\mathrm{v} / \mathrm{v})$ solution for 20 minutes (with shaking), dried at room temperature for 30 minutes, and rehydrated with a reducing solution (10 mM EDTA, $10 \mathrm{mM}$ dithiothreitol, 100 $\mathrm{mM} \mathrm{NH} \mathrm{HCO}_{3}$ ). The gel portion was alkylated by iodoacetamide. Enzymatic cleavage was initiated by adding a 50-mM ammonium bicarbonate solution containing trypsin (Promega, Lyon, France) and lysylendopeptidase (LEP; Wako Pure Chemical 
Industries, Ltd., Osaka, Japan). After absorption of the protease solution, aliquots $(10 \mu \mathrm{L})$ of 50 $\mathrm{mM}$ ammonium bicarbonate solution containing $5 \mathrm{mM}$ calcium chloride were added sequentially and digested for 16 hours at $37^{\circ} \mathrm{C}$. To recover hydrophobic peptides, the samples were extracted using $50 \%$ acetonitrile containing $2.5 \%$ formic acid. Pooled extracts were concentrated using a centrifugal concentrator and then desalted using a ZipTip $\mu$ C18 (Millipore, Bedford, MA, USA).

Peptides were resolved with $3 \mu \mathrm{L}$ of $75 \%$ acetonitrile $/ \mathrm{H}_{2} \mathrm{O}(\mathrm{v} / \mathrm{v})$ containing $0.1 \%$ trifluoroacetic acid and then diluted with $12 \mu \mathrm{L}$ of $1 \%$ formic acid. The digestion mixture was applied to a reversedphase column (Zorbax 300S-C18, $3.5 \mu \mathrm{m}, 150 \times 0.3$ $\mathrm{mm}$, Agilent, Santa Clara, CA, USA) in a capillary HPLC (Agilent 1100 system, Agilent). The column was eluted with a gradient of $10-65 \%$ acetonitrile in $0.1 \%$ formic acid at a flow rate of $4 \mu \mathrm{L} /$ minutes. Ion-trap mass spectrometry (LC-MS/MS) was performed with an HCT Ultra SI (Bruker Daltonics, Bremen, Germany), according to the manufacturer's instructions. MS/MS spectra were searched against a protein database provided by the Swiss Institute of Bioinformatics, using the MASCOT MS/MS ions search server (Matrix Science, Boston, MA, USA).

\section{Statistical analysis}

All data was obtained from at least three independent experiments, each performed in
A

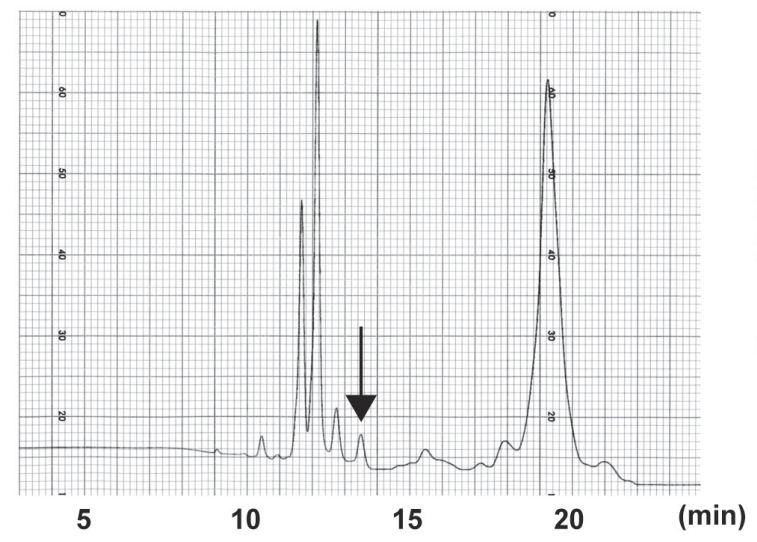

C

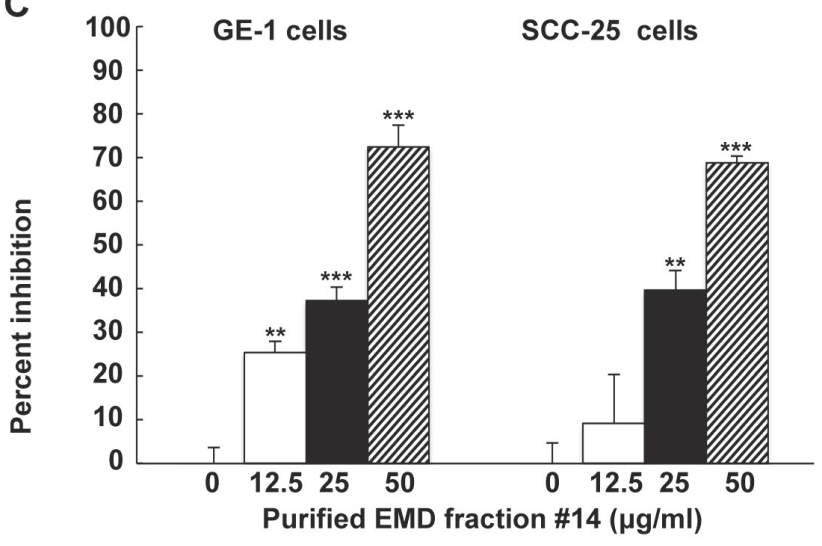

B

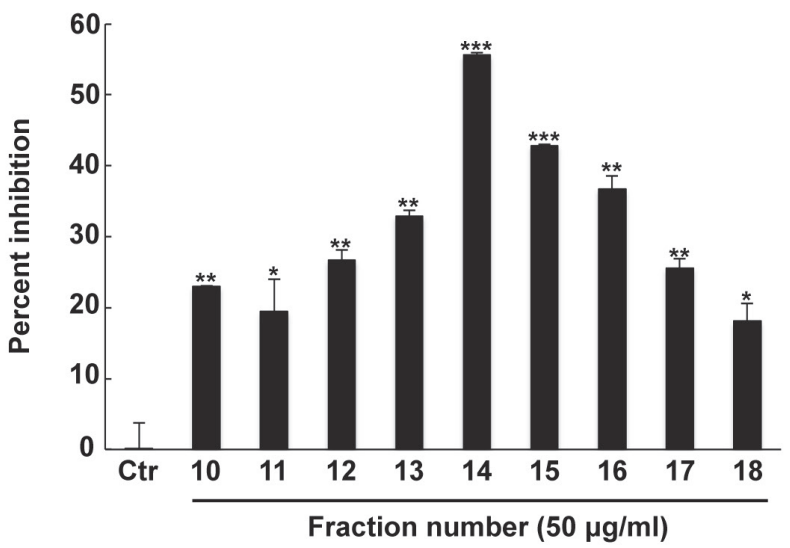

D

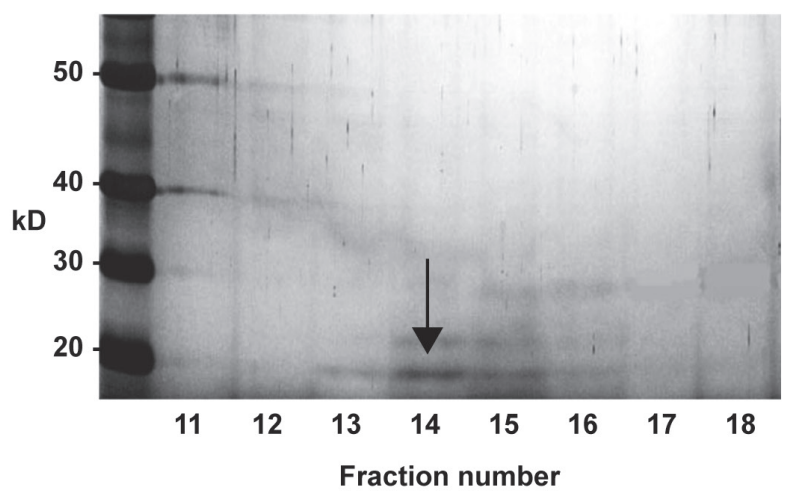

Figure 1- Effects of purified enamel matrix derivative (EMD) fractions on epithelial cell proliferation. (A) Results of reversedphase high-performance liquid chromatography (HPLC) using C18 hydrophobic support. Lyophilized EMD was dissolved in $0.1 \%$ TFA, applied to reversed-phase HPLC, and eluted at $0.5 \mathrm{~mL} /$ minute. The arrow indicates the bioactive peak; (B) GE-1 cells were stimulated with each fraction $(50 \mu \mathrm{g} / \mathrm{mL})$ for 48 hours. Cell viability was determined using WST-1 analysis. The data show the percentage inhibition of cell proliferation from independent samples $(n=3)$. The bars represent mean \pm standard deviation. Data was analyzed by Dunnett's test after one-way ANOVA $\left({ }^{*} P<0.05,{ }^{* *} P<0.01,{ }^{* * *} P<0.0001\right.$ vs untreated control); (C) GE-1 and SCC-25 cells were separately cultured for 48 hours in the presence of $0-50 \mu \mathrm{g} / \mathrm{mL}$ of bioactive fraction number 14 , after which cell viability was determined using WST-1 analysis. The data shows the percent inhibition of cell proliferation from independent samples $(n=3)$. The bars represent mean \pm standard deviation. Data was analyzed by Dunnett's test after one-way ANOVA ( ${ }^{* *} \mathrm{P}<0.01$, ${ }^{* * *} \mathrm{P}<0.0001$ vs untreated control); (D) Proteins of each fraction (numbers 11-18) were visualized by SDS-PAGE followed by silver staining 
triplicate. Statistical analyses were conducted using $\mathrm{JMP}^{\circledR}$ software, version 10.0.2 (SAS Institute Inc., Cary, NC, USA). All data was expressed as mean \pm standard deviation and analyzed by one-way analysis of variance (ANOVA) followed by Dunnett's post test. A $P$ value of less than 0.05 was considered to indicate statistical significance.

\section{RESULTS}

\section{Effects of purified fractions of EMD on epithelial cell proliferation}

As shown in Figure $1 \mathrm{~A}$, both major and minor peaks were detected, and $0.5-\mathrm{mL}$ fractions were collected at a flow rate of $0.5 \mathrm{~mL} /$ minute, lyophilized, and dissolved in the culture medium. To determine the effects on cell viability, epithelial cells were treated with purified EMD fraction (numbers 1-40) for 44 hours, after which cell survival was assessed with a WST-1 assay. Culturing with each fraction (numbers 10-18) suppressed the proliferation of epithelial cells, whereas the other fractions had no effect on cell growth (data not shown). Among the fractions, number 14 had the highest inhibitory activity against GE-1 cells (Figure 1B) and also significantly inhibited proliferation of SCC- 25 cells in a dose-dependent manner up to 50 $\mu \mathrm{g} / \mathrm{mL}$ (Figure $1 \mathrm{C}$ ). Silver staining revealed 15-20 $\mathrm{kDa}$ proteins in fraction 14 (Figure 1D), which was eluted with $35 \%$ acetonitrile in $0.1 \%$ TFA.

\section{Proteome analysis of bioactive fractions of EMD}

To identify the proteins in bioactive fractions of EMD, we used proteome analysis with twodimensional gel electrophoresis (2DE) followed by identification with mass spectrometry. Figure $2 \mathrm{~A}$ shows the separate proteins extracted from the bioactive EMD fractions by 2DE and SDS-PAGE. Some of the proteins were resolved on SDS-PAGE gels, the most abundant of which had a molecular mass of approximately $17 \mathrm{kDa}$. A total of 5 spots were chosen (Figure $2 \mathrm{~B}$ ) and analyzed for protein identification. As shown in Figure 3, fraction 14-3
A

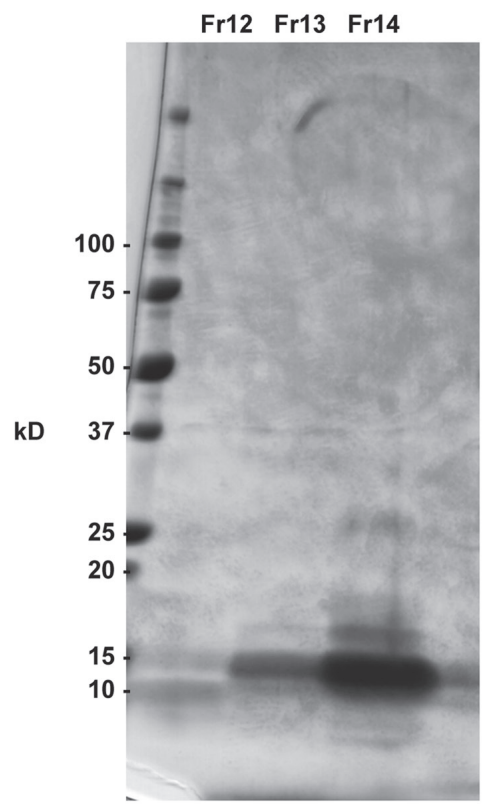

B

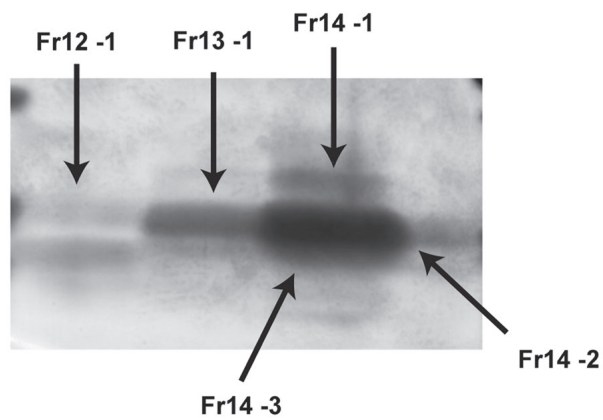

Figure 2- Proteome analysis of bioactive enamel matrix derivative (EMD) fractions. (A) Separation of proteins in bioactive EMD fractions and visualization of protein bands by silver staining. The vertical axis represents molecular mass ( $k D a)$; $(B)$ Semiquantitative variation of protein spots among bioactive EMD fractions

\begin{tabular}{|c|c|c|c|}
\hline Sample & Accession & Identified Protein & Sequence \\
\hline Fr12-1 & - & ND & - \\
\hline Fr13-1 & - & ND & - \\
\hline Fr14-1 & - & ND & - \\
\hline Fr14-2 & - & Serum albumin & Ameloblastin \\
\hline Fr14-3 & Q28989 & EHETQQPSLQPQQPGQK \\
\hline
\end{tabular}

$\mathrm{ND}=$ not detected

Figure 3- Identified peptides in protein spots among bioactive fractions of enamel matrix derivative (EMD) by LC-MS/MS. 
A

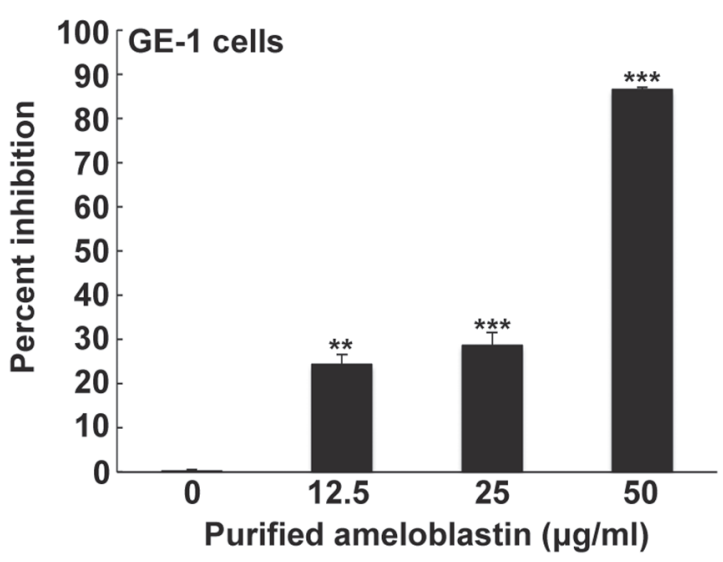

B

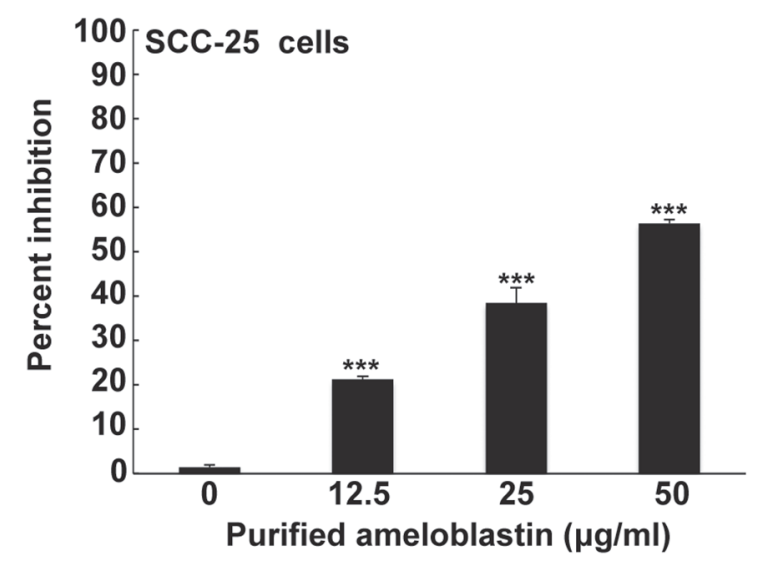

Figure 4- Effects of recombinant ameloblastin on epithelial cell proliferation. GE-1 (A) and SCC-25 (B) cells were separately stimulated with recombinant ameloblastin protein for 48 hours, after which cell viability was determined using WST-1 analysis. The data shows the percent inhibition of cell proliferation from independent samples $(n=3)$. The bars represent mean \pm standard deviation. Data was analyzed by Dunnett's test after oneway ANOVA ( ${ }^{* *} \mathrm{P}<0.01,{ }^{* * *} \mathrm{P}<0.0001$ vs untreated control)

contained ameloblastin.

\section{Effects of recombinant ameloblastin on epithelial cell proliferation}

To examine the role of ameloblastin on epithelial cell growth, we used affinity gel to create FLAGtagged recombinant ameloblastin. Proliferation of GE-1 (Figure 4A) and SCC-25 (Figure 4B) cells was inhibited in a dose-dependent manner when the cells were cultured with recombinant ameloblastin.

\section{DISCUSSION}

We found that EMD inhibited the proliferation of mouse gingival epithelial and human oral squamous carcinoma cells. These findings are consistent with those of a previous study, which reported dose- dependent inhibition of oral epithelial cell division by $E M D^{16}$. To investigate the effects of EMD on the proliferation of gingival epithelial cells, we examined the biological and chemical properties of EMD.

Bioactive fractions that inhibited epithelial cell proliferation were purified using reversed-phase HPLC and $\mathrm{C}_{18}$ column. As shown in Figure $1 \mathrm{~A}$, fractions that inhibited epithelial cell proliferation were detected as minor peaks, after elution with $31 \%$ acetonitrile in $0.1 \%$ TFA. These bioactive fractions also inhibited the proliferation of GE-1 and SCC-25 cells (Figure $1 \mathrm{~B}$ and $1 \mathrm{C}$ ). Our findings indicate that EMD contains bioactive molecules that suppress epithelial proliferation. Furthermore, SDSPAGE analysis showed that EMD contains several proteins and peptides with molecular weights of 15-20 kDa (Figure 1D).

To identify the molecules that inhibit epithelial cell proliferation, the bioactive fractions were separated using 2DE and identified using MS. Proteomics with 2DE, MS, and database searches are a powerful method for determining the composition of complex combinations of proteins ${ }^{2,4}$. We identified ameloblastin in bioactive EMD fractions (Figures 2 and 3). Previous studies noted that EMD contains glycoprotein, amelogenin, and non-amelogenin proteins (e.g., ameloblastin and enamelin) at a ratio of approximately $90: 10^{24,25}$, which suggests that ameloblastin is a minor component with high biological activity.

Ameloblastin, also known as amelin or sheathlin, is the most abundant non-amelogenin enamel matrix protein ${ }^{3,5,17}$. Recently, endogenous ameloblastin has been identified in many non-dental tissues including mandibular alveolar bones and basal bones but also in several soft tissues including eyes, tongues and testicles ${ }^{15}$. These findings suggest that ameloblastin functions as growth factor-like molecule and has an important role beyond the control of enamel mineralization. However, less attention has been paid to the effects of ameloblastin on epithelial cell proliferation. To explore the potential functions of ameloblastin in epithelial cell proliferation, we purified FLAG-tagged recombinant proteins in this study.

Recombinant ameloblastin inhibited epithelial cell proliferation in vitro (Figure 4). Our results suggest that ameloblastin is the principal bioactive factor in EMD in inhibiting epithelial cell proliferation. Recent study revealed that lower a concentration (12.5-100 $\mathrm{ng} / \mathrm{ml}$ ) of recombinant human ameloblastin purified using HaloTag ${ }^{\circledR}$ fusion tag system suppressed the proliferation of SCC- 25 cells $^{23}$. We have no ready explanation for these discrepancies, though it is possible that they reflect differences in the purification procedure of recombinant protein. However, a previous study showed that EMD stimulated proliferation of human periodontal 
cells, as well as epithelial cell rests of Malazzez, gingival fibroblasts, and osteoblasts ${ }^{9}$. In addition, recombinant ameloblastin has been shown to stimulate the proliferation of human mesenchymal stem cells and osteoblasts ${ }^{26}$. Together, these findings indicate that the effect of ameloblastin on cell proliferation varies according to cell type. Additional experiments using recombinant molecules are needed in order to clarify the cellspecific activities of these fractions. Previous studies have provided some information on the role of ameloblastin in adhesion and proliferation in various cell types ${ }^{13,27,28,30}$.

Our findings are strongly supported by the previous studies in which the proliferation of SCC-25 cells was shown to be inhibited via cell cycle arrest at $\mathrm{G} 1$ phase in response to EMD ${ }^{16}$ or ameloblastin ${ }^{23}$. Furthermore, the binding of enamel matrix proteins to specific proteins including fibronectin and type I collagen regulates their adhesive properties, leading to modulate fibroblast adhesion to epithelial cells ${ }^{19}$. Additional molecular studies are required in order to better understand the specific signaling pathway for ameloblastin in epithelial cells.

The ideal agent for promoting periodontal regeneration would not only stimulate regeneration of connective and bone tissues but also inhibit epithelial downgrowth, which frequently interferes with formation of a new connective tissue attachment. Our results show that ameloblastin inhibits epithelial cell proliferation, indicating that it may be important in periodontal tissue repair.

\section{ACKNOWLEDGMENTS}

This research was supported by the Seikagaku Corporation, which provided the EMD used in this study.

\section{REFERENCES}

1- Bosshardt DD. Biological mediators and periodontal regeneration: a review of enamel matrix proteins at the cellular and molecular levels. J Clin Periodontol. 2008;35(8 Suppl):87-105. 2- Cañas B, López-Ferrer D, Ramos-Fernández A, Camafeita E, Calvo E. Mass spectrometry technologies for proteomics. Brief Funct Genomic Proteomic. 2006;4(4):295-320.

3- Cerný R, Slaby I, Hammarström L, Wurtz T. A novel gene expressed in rat ameloblasts codes for proteins with cell binding. J Bone Miner Res. 1996;11(7):883-91.

4- Fenselau C. A review of quantitative methods for proteomic studies. J Chromatogr B Analyt Technol Biomed Life Sci. 2007;855(1):14-20.

5- Fong CD, Cerný R, Hammarström L, Slaby I. Sequential expression of an amelin gene in mesenchymal and epithelial cells during odontogenesis in rats. Eur J Oral Sci. 1998;106(Suppl 1):324-30.

6- Gestrelius S, Andersson C, Johansson AC, Persson E, Brodin $A$, Rydhag $L$, et al. Formation of enamel matrix derivative for surface coating. Kinetics and cell colonization. J Clin Periodontol. 1997;24(9 Pt 2):678-84.
7- Gestrelius S, Andersson C, Lidström D, Hammarström L, Somerman M. In vitro studies on periodontal ligament cells and enamel matrix derivative. J Clin Periodontol. 1997;24(9 Pt 2):685-92.

8- Grandin HM, Gemperli AC, Dard M. Enamel matrix derivative: a review of cellular effects in vitro and a model of molecular arrangement and functioning. Tissue Eng Part B Rev. 2012;18(3):181-202.

9- Graves DT, Conchran D. The contribution of interleukin-1 and tumor necrosis factor to periodontal tissue destruction. J Periodontol. 2003;74(3):391-401.

10- Gruber R, Roos G, Caballé-Serrano J, Miron R, Bosshardt DD, Sculean A. TGF- $\beta$ RI kinase activity mediates Emdogain-stimulated in vitro osteoclastogenesis. Clin Oral Investig. 2014;18(6):163946.

11- Gruber R, Stähli A, Miron RJ, Bosshardt DD, Sculean A. Common target genes of palatal and gingival fibroblasts for EMD: the microarray approach. J Periodontal Res. 2015;50(1):103-12. 12- Hammarström L. Enamel matrix, cementum development and regeneration. J Clin Periodontol. 1997;24(9 Pt 2):658-68.

13- Iizuka S, Kudo Y, Yoshida M, Tsunematsu T, Yoshiko Y, Uchida $\mathrm{T}$, et al. Ameloblastin regulates osteogenic differentiation by inhibiting Src kinase via crosstalk between integrin beta1 and CD63. Mol Cell Biol. 2011;31(4):783-92.

14- Itoh N, Kasai H, Ariyoshi W, Harada E, Yokota M, Nishihara T. Mechanisms involved in the enhancement of osteoclast formation by enamel matrix derivative. J Periodont Res. 2006;41(4):273-9. 15- Jacques J, Hotton D, De la Dure-Molla M, Petit S, Asselin $A$, Kulkarni $A B$, et al. Tracking endogenous amelogenin and ameloblastin in vivo. PLoS One. 2014;9(6):e99626.

16- Kawase T, Okuda K, Yoshie H, Burns DM. Cytostatic action of enamel matrix derivative (EMDOGAIN) on human oral squamous cell carcinonma-derived SCC25 epithelial cells. J Periodont Res. 2000;35(5):291-300.

17- Krebsbach PH, Lee SK, Matsuki Y, Kozak CA, Yamada KM, Yamada Y. Full-length sequence, localization, and chromosomal mapping of ameloblastin. A novel tooth-specific gene. J Biol Chem. 1996;271(8):4431-5.

18- Madianos PN, Bobetsis YA, Kinane DF. Generation of inflammatory stimuli: how bacteria set up inflammatory responses in the gingiva. J Clin Periodontol. 2005;32(Suppl 6):57-71.

19- Narani N, Owen GR, Häkkinen L, Putnins E, Larjava H. Enamel matrix proteins bind to wound matrix proteins and regulate their cell-adhesive properties. Eur J Oral Sci. 2007:115(4):288-95.

20- Otsuka T, Kasai H, Yamaguchi K, Nishihara T. Enamel matrix derivative promotes osteoclast cell formation by RANKL production in mouse marrow cultures. J Dent. 2005;33(9):744-55.

21- Pinchback JS, Gibbins JR, Hunter N. Vascular co-localization of proteolytic enzymes and proteinase inhibitors in advanced periodontitis. J Pathol. 1996;179(3):326-32.

22- Reynolds JJ, Hembry RM, Meikle MC. Connective tissue degradation in health and periodontal disease and the roles of matrix metalloproteinases and their natural inhibitors. Adv Dent Res. 1994;8(2):312-9.

23- Saito N, Ariyoshi W, Okinaga T, Kamegawa M, Matsukizono M, Akebiyama $Y$, et al. Inhibitory effects of ameloblastin on epithelial cell proliferation. Arch Oral Biol. 2014;59(8):835-40.

24- Schwartz Z, Carnes DL Jr, Pulliam R, Lohmann $\mathrm{CH}$, Sylvia $V L$, Liu $Y$, et al. Porcine fetal enamel matrix derivative stimulates proliferation but not differentiation of pre-osteoblastic 2T9 cells, inhibits proliferation and stimulates differentiation of osteoblastlike MG63 cells, and increases proliferation and differentiation of normal human osteoblast NHOst cells. J Periodontol. 2000;71(8): 1287-96.

25- Shimizu-Ishiura M, Tanaka S, Lee WS, Debari K, Sasaki T. Effects of enamel matrix derivative to titanium implantation in rat femurs. J Biomed Mater Res. 2002;60(2):269-76. 
26- Tamburstuen MV, Reppe S, Spahr A, Sabetrasekh R, Kvalheim G, Slaby I, et al. Ameloblastin promotes bone growth by enhancing proliferation of progenitor cells and by stimulating immunoregulators. Eur J Oral Sci. 2010;118(5):451-9.

27- Vymetal J, Slabý I, Spahr A, Vondrásek J, Lyngstadaas SP. Bioinformatic analysis and molecular modelling of human ameloblastin suggest a two-domain intrinsically unstructured calcium-binding protein. Eur J Oral Sci. 2008;116 (2):124-34. 28- Wang H, Tannukit S, Zhu D, Snead ML, Paine ML. Ename matrix protein interactions. J Bone Miner Res. 2005;20(6):103240.
29- Weinberg E, Topaz M, Dard M, Lyngstadaas P, Nemcovsky C, Weinreb $M$. Differential effects of prostaglandin $E(2)$ and enamel matrix derivative on the proliferation of human gingival and dermal fibroblasts and gingival keratinocytes. J Periodontal Res. 2010;45(6):731-40

30- Zhang X, Diekwisch TG, Luan X. Structure and function of ameloblastin as an extracellular matrix protein: adhesion, calcium binding, and CD63 interaction in human and mouse. Eur J Oral Sci. 2011;119(Suppl 1):270-9. 